\title{
The Museumification of Treasure Hill: Authenticity, Authority and Art in a Taiwanese Urban Village
}

\author{
Igor Rogelja
}

This article discusses the "museumification" of an urban village in Taipei into the Treasure Hill Artist Village in the context of wider debates on gentrification and the redevelopment of marginal urban spaces. Populated by soldiers evacuated to Taiwan following the Chinese Civil War, Treasure Hill became a hybrid space, combining welfare provision for elderly veterans with an artist colony, forming part of the Taipei Cultural Foundation. Lauded as a compromise that combined social, cultural and economic aspects of urban regeneration, the mix of high-modernist paternalism and neoliberal place-making resulted in the integration of the space into the existing city bureaucracy as a museum-like institution, with elderly residents and artists becoming exhibits in a living diorama. Although widely understood as "gentrification" at the time, the article argues that the museumification of Treasure Hill was a process led by a coalition of state and spatial experts which has distinct implications for the study of state-led neighbourhood amelioration.

Keywords: museumification; creative city; Taiwan; gentrification; authenticity

The unique location of Treasure Hill with its narrow alleys and stairways traversing the hillside, gives THAV [Treasure Hill Artist Village] a European rural village feel. Over the years, various groups settled the hillside with their own lifestyles and needs creating a tribal-like organic scene. With the existing residents, together with the urban policy of preservation and revitalization, the Artist-in-Residence program and Youth Hostel it is hoped that the parties will collaborate in the spirit of "paragenesis" to create a better future of the entire community.

Taipei Culture Foundation website: Treasure Hill Artist Village ${ }^{1}$

Although only a ten-minute walk from the busy streets of Gongguan 公館, a lively area of Taipei near the National Taiwan University, the haphazard collection of houses clinging to the steep face of Treasure Hill (Baozangyan 寶藏嚴) has long remained a place visually and geographically separated from the surrounding urban fibre. In its aesthetic and spatial separation, the small settlement was characterized by the vernacular cultures of successive waves of migration, most notably the soldiers and their families who fled to Taiwan after the Communist victory in the Chinese Civil War but also migrants from the countryside and South-East Asia, and young artists looking for a cheap and inspiring studio location. As an illegal and unplanned settlement, this complex and layered space was earmarked for demolition in 1980, yet it survived decades of uncertainty and was finally recognized as a special historical settlement and re-opened as the Treasure Hill Artist Village (THAV) in October 2010.

This article begins by asking how Treasure Hill avoided demolition to become a hybrid space of cultural conservation and welfare provision. Specifically, it interrogates what role experts and activists played in the institutionalization of authenticity. Starting from this research question, the article argues that the official narrative of an orderly, collaborative transition from illegal settlement to artist village obscures a more nuanced process: a negotiation through which the use value of a 
marginal settlement (a cheap, accessible and safe dwelling for new arrivals into the city) was converted to a consumable value as a tourist destination that was replete with a curated version of Taiwan's past, appropriating the spatial culture of the village's builders into a city-wide vision of Taipei as an authentic, creative city. Simultaneously, it is contended that this process, while taking some of the airs of gentrification, is in fact best described as "museumification," that is, the transformation of an urban space into a visitor-oriented, curated, publicly administered institution. The present case therefore contributes a more layered view of post-industrial urban transformations in East Asia and beyond by exploring the role of expertise and the state in culture-led urban redevelopment.

Contextualizing this museumification within the creative city discourse ${ }^{2}$ (most notably shaped in Taiwan by Charles Landry ${ }^{3}$ ), as well as the discourse on Taiwanese identity, it has been possible to analyse how groups of spatial experts were able to achieve the village's preservation by integrating it into the city's administrative framework. ${ }^{4}$ In doing so, they created an institution that administers not only studios and galleries but also the original residents who kept their right to reside in the village. While the size of the project is small, this article argues that the scope of governing is large. As such, the transformation can be examined through a political ethnography of space, analysing (a) the way in which civil society groups came to shape the village within the framework of the state's bureaucratic management and (b) the resulting museumification and its implications for the regeneration of other marginal spaces in Taipei as well as its application in urban studies at large.

The starting point of this research was a survey of the spatial and managerial arrangement that resulted from a series of compromises between four key groups: the residents, expert civil society groups, squatter activists and the municipality. I conducted fieldwork between the autumn of 2012 and the summer of 2013, during which time I visited the site 18 times, both on weekdays and weekends as well as in different weather conditions/seasons to establish a clearer image of how the site works as an outdoor attraction, who visits it, what the relations between the different users are, and how the artist village operates daily. Long(er) term observation was complemented with semi-structured interviews with members of staff and managers, resident artists (both international and domestic) and former activists, as well as with more casual conversations with the area's many visitors. In total, I conducted 30 interviews and conversations. The objective was not to provide a quantitative representation of opinion but rather to uncover how the users of this space conceive of it themselves and how their stories and opinions were used by the key groups mentioned above. This ethnography of space was contextualized through archival research of contemporaneous news reports and broadcasts, articles, blogs, bulletin boards, pamphlets, petitions, amateur video clips as well as (mainly Taiwanese) academic writing on the topic of the artist village over a period of around 15 years from 1999 onwards. Owing to the large amount of "grey literature" examined, claims and counterclaims were not taken as factual; rather they represent anecdotal evidence used to interpret the institutional makeup as well as the building blocks of a wider narrative on the emergence of a new authenticity and authority during the process of museumification.

\section{Authenticity and Authority in a Migrant Settlement}

Populated mainly by elderly military personnel from mainland China, Treasure Hill shares the fate of many “military dependents' villages" (juancun 眷村) which housed Nationalist troops after their defeat in the Chinese Civil War. Although the extant part 
of Treasure Hill was in fact not an official juancun, its authenticity, as defined by the villages' conservationists, stems from a position of dual marginalization (both economic and cultural) typical of such veterans' villages. ${ }^{5}$

These military settlements were a direct consequence of the Kuomintang regime's hold on Taiwan, which Allen Chun has described as "a kind of colonialism which was no less 'foreign' than the Japanese interregnum that preceded it." "For many islanders, retrocession to China was a continuation of a colonial relationship between themselves and the colonizing power. ${ }^{7}$ Furthermore, the systemic favouring of mainlanders (waishengren 外省人) over indigenous Taiwanese has lead Liu to even define Taiwan as a “settler state," i.e. one that is ruled by an exogenous group. ${ }^{8}$ Military personnel were not able to interact with the majority population owing to linguistic barriers but neither were they part of the Kuomintang elite. ${ }^{9}$ Once dreams of retaking China were finally abandoned, the temporary shacks and barracks housing the Republican army soldiers became permanent shanties. Aided by the government's permissive neglect, these settlements developed unique spatial and social structures to cope with their marginal status: shared kitchens, communal meals, architecturally intertwined buildings where one resident's roof was a neighbour's terrace. As economic success spurred the rapid redevelopment of Taiwan's urban centres, however, the juancun increasingly became the targets of the "green bulldozer" as poor, illegally built neighbourhoods were levelled to make way for parks. ${ }^{10}$ The island's contentious politics following democratization further complicated the status of the juancun, with the opposition Democratic Progressive Party (DPP) viewing any compensation or appeasement of the now elderly military personnel as favouring "mainlanders" over "Taiwanese" - whatever those terms meant by then. ${ }^{11}$ By the 1990 s, such idiosyncratic places came to be recognized as authentically "Taiwanese." Treasure Hill was not unique in this: other dilapidated areas of the city became the focus of artistic, literary and conservational work. Yomi Braester noted that film crews looking for authentic sets would often bump into each other in the rapidly disappearing veterans' villages of Taipei. ${ }^{12}$

The concept of the authentic has been much discussed in anthropology, ${ }^{13}$ shifting from a purely museological term (authentic as opposed to fake), to a discussion on the production of authenticity, its interaction with viewers or researchers, its materiality, circulation and transformations. Tom Selwyn, for example, suggests a dichotomy of "cool" authenticity as knowledge and "hot" authenticity as feeling. ${ }^{14}$ John Urry's "tourist gaze" similarly relies on socio-cultural framing, ${ }^{15}$ with the gaze being structured through gender, age, ethnicity or class. ${ }^{16}$ The ability to appreciate what is displayed and what is authentic is thus learned, received and constructed. In this article, authenticity is identified primarily as a construct which spatial experts use to justify both preservation ("cold" - authenticity as knowledge) and the subsequent museumification of space ("hot" - visitors" feeling of authenticity). As Slavoj Žižek puts it, however, authenticity also "resides in the act of violent transgression." seemingly distant from the discussion at hand, the idea of transgression fits Treasure Hill well - the "authentic" veteran village existed outside of its own daily reality as well as in its separation from the city surrounding it. As such, authenticity was an incursion - the authenticity of Treasure Hill had to be found and mapped by outsiders trying to protect it from demolition and not by those who built and inhabited it.

In the case of Treasure Hill, the search for authenticity, carrying within it dominant narratives of what is authentic and what is not, became a municipally formalized one. The idea of an authentic migrant village pervaded the conservation effort at Treasure Hill, from romanticized assumptions about its look ("a European rural 
village feel"), to bureaucratic practices regulating it, and post-industrial creative city notions on art as a panacea to social problems. In short, authenticity in this case acted as a "truth claim." Following Lisa Wedeen's call for an interpretive political science which uses ethnographic methods precisely to situate such truth claims in a broader context to show how they operate, this article proceeds by analysing how the authenticity of the village came to be fixed within a process of institutionalization, from an organic migrant and veteran village to a village-like museum, and then contrasts this with the phenomenon of gentrification. ${ }^{18}$

Through a political ethnography of the space, the article argues that authenticity is closely connected to the interlocking authorities of spatial expert-activists and the municipal government, resulting in the insertion of the activists' understanding of space into bureaucratic practice. The concept of interlocking authorities owes much to a nonzero-sum view of authority, which Abers and Keck apply to their work on practical authority in Brazil's water politics. They define practical authority as an accumulation of capabilities and recognition by actors within a particular policy field that enables them to influence the actions of others but equally focus on the "practices that actors invent and deploy when they try to create new sites of practical authority."19

Museumification in this context enabled the formalization of expert authority within the state's bureaucracy and enabled the preservation of Treasure Hill's buildings and (some) residents. Previous work on museumification has focused more on its identity-building aspect, ${ }^{20}$ the relation to memory and place, ${ }^{21}$ or on the link between historicization, memory work and commercial enterprise. ${ }^{22}$ The present article builds upon such work by exploring the spatial nature of museumification and, in doing so, brings some relief to the over-stretched concept of gentrification, which has come to denote more than its fair share of urban spatial phenomena. The case also bears some similarity to "eco-museums," although these are by definition community-run spaces. Treasure Hill may have started as an eco-museum but it quickly ended up entangled within the matrix of the city's cultural and welfare administration, with specific work even outsourced to for-profit enterprises. Ironically, many early eco-museums have since experienced similar issues with preserving community engagement and are drifting towards more conventional museum forms. ${ }^{23}$ This article adds to this literature by tracing how the expert authority of conservationists and other activists produced an authenticity that acted as the precursor to lasting museumification of the urban village.

By identifying a gap within the municipal and national bureaucracy (the question of how to govern authenticity as an amalgam of culture and welfare), spatial experts asserted their authority over the process of integrating the village into the municipal framework. They redefined the problem as a heritage preservation issue and connected it to a post-industrial understanding of culture as an economic resource, a concept which can be traced back to the US and Britain in the $1980 \mathrm{~s}^{24}$ In Treasure Hill, however, expert groups also had to contend with elderly residents, whose welfare needs they connected to heritage preservation, making them the living heritage of the museum-village. The experts' authority was exerted not so much over residents or artists but over the process of redeveloping the village. As the empirical part of the article shows, the authority of expert-activists here hinges not on persuasion or force but on a shared reading of interests and practice as well as a mutually recognized hierarchical position with the municipality. Although expert groups had a history of opposing the municipal state in previous cases, such as in the demolition of the Kangleli 康樂裡 juancun, the present article shows how they ended up sharing with the city authorities what Miller and Rose would call a "technology of government" that relies on a loose alignment of interests as well as shared vocabularies, theories and 
explanations. ${ }^{25}$ The success of the spatial experts in inserting themselves in the decision-making process at Treasure Hill was therefore contingent on a mutual intelligibility between them and the municipality. In this case, this included shared ideas about the value of waishengren culture within a larger discourse on Taiwan as a culturally diverse place (which was a diversity acceptable to the Kuomintang-run city government). Moreover, there were commonalities regarding the managerial approaches to governing a problematized population. These commonalities were present in the experts' work from the very first report on the site: all three options presented envisaged a leading role for the municipal bureaucracy and addressed the city's concerns over maintaining public ownership of land. ${ }^{26}$ The acknowledgement and integration of expert practices by the municipality has furthermore shaped pathdependencies in conflicts and decisions over the integration of other marginal spaces in Taipei. ${ }^{27}$ The way in which Treasure Hill was integrated into the city is therefore particularly appropriate as a political case study of the microcosm of one urban village's transition from Taipei's favela to its first cohabitational museum. The following sections loosely follow this scheme by weaving the empirical findings through an analysis of museumification in two distinct stages: an archival investigation into the mode of preservation that transformed it, and an ethnography of the current institutional setup through which it is run.

\section{Treasure Hill 1: From Demolition to Preservation}

My first encounter with Treasure Hill came in 2004 at just around the time that its status was being formalized by the city's cultural bureau. At that time, artists were still squatting buildings and organized regular events and parties. The community of migrant war veterans living in the shadow of Guanyin Temple 觀音亭 had by then shrunk considerably. Many had died or else had moved away either voluntarily or owing to a series of demolition and resettlement initiatives implemented by the city authorities from 1980 onwards that began with the official military settlement under the hill in 1994 and progressed to the riverside area, which was demolished in 2002. Treasure Hill was on the cusp of the most significant change in its status since the first proposals to demolish it some 23 years earlier - it was to become managed by the city's cultural department as a formally established international artists' village. In early 2007 , all residents and artists were moved out of the village, although some could return to their houses after a period in temporary lodgings while the houses they built were being renovated according to city-approved plans. The residents' right of return was not automatic but was based on their welfare status as well as the occupants' previous decisions. Some households had accepted an earlier compensation package and thus lost their right of return regardless of their income.

The current arrangement at Treasure Hill may mimic an organically grown space, but it is a carefully planned and tended one, more akin to a garden than a meadow. When I began my first stint of fieldwork, the managing team of the THAV indicated that the administration was wary of research on site and that permission was needed from them to talk to any resident or artist. Were this a genuine village, this would have struck me as unusually repressive. Yet, while outwardly retaining the look of a hillside village, Treasure Hill is a cultural organization with a unified managerial structure overseeing the many component parts: studios, exhibition spaces, cafes, shops, a youth hostel, offices and 21 original households (19 in 2018) that retained the right to inhabit the houses they built.

Following renovation, the remaining households rented the refurbished houses on a 12-year tenancy agreement with the Department of Cultural Affairs (via an 
involved NGO, the Tsuei Mama Housing Foundation (Cui Mama Jijinhui 崔媽媽基金 會), the renewal of which will be decided at a later date following negotiations between the community and the city. ${ }^{28}$ In addition to the households, the village hosts one or two international and a similar number of domestic artists-in-residence at any time who live on site for periods ranging from two to seven months. Most of the remaining space is let out for affordable rent (between \$100-\$230 per month) under the "Micro Loft" programme, which hosts around 15 small ventures from studios and workshops, to cafes and shops, all of which were allocated space based on their application to the Taipei Culture Foundation (a quasi-NGO tasked with overseeing the Artist Village). Separate from these subcontracted areas, the THAV also runs a youth hostel as well as some peripheral tourist amenities and information points. Below the village, lawns, garden allotments and open spaces (see Figure 1) link it with the path from Guting Riverside Park 古亭河濱公園, which is popular with walkers and cyclists alike. Both permanent and temporary art installations are scattered around the hilly area, which is also heavily signposted so that visitors are able to read about the history of the village.

[Figure 1]

The conflicts and negotiations that led to the settlement's evolution from organic village to curated village-like museum do not form part of its official history. What is most unusual about Treasure Hill is not that the physical structures of the village were spared destruction - the remote and hilly location survived the assault on marginal urban spaces that was launched in the 1980s and 1990s, by which time an awareness of the value of war veterans' villages had already been established following popular disapproval of the larger urban redevelopment project in Kangleli in Taipei in 1997. ${ }^{29}$ Rather, what sets Treasure Hill apart is that the idea of authenticity included its living culture - the residents of the village - and that the setting up of the village as a public institution was entrusted to expert groups. The management of the settlement became an exercise in governing a specific population, within the framework of the "cohabitation" of residents and artists, and by a non-state actor whose authority was nevertheless recognized by the state.

In the case of Treasure Hill, cohabitation was to be achieved by using art and creativity within a "culture-welfarist" project that combines welfare provision with cultural infrastructure. The timing may be crucial in this case: the arrival onto the scene of a charismatic new KMT mayor, Ma Ying-jeou 馬英九 (who later became Taiwan's president), contextualizes the willingness of the municipality to integrate new ways of governing urban spaces, particularly after the stand-offs between civil society groups and the previous DPP-led city administration. Once he was elected, Ma enlisted expert groups to produce a report on potential demolition and resettlement plans in 1999. These included the "Organization of Urban Re-s" (OURs), ${ }^{30}$ the aforementioned Tsuei Mama Foundation and the Yaoshan Cultural and Education Foundation (Yaoshan wenjiao jijinhui 樂山文教基金會), led by conservationist Qiu Ruhua 丘如華 and subsequently renamed as the Taiwan Institute of Historical Resource Management (Taiwan lishi ziyuan jingli xuehui 台灣歷史資源經理學會). This core group of respected civil society leaders found an ally in the first director of the city's Cultural Affairs Bureau, Taiwanese writer Lung Ying-tai 龍應台, who was instrumental in introducing the concept of the "poor art village" as an optic through which Treasure Hill was viewed by the municipality. Originating from her circle of advisors at the department, the concept stems from the arte povera movement in Italian art. ${ }^{31}$ Stripped of its radicalism (or perhaps wholly misunderstood), it became one of the foundations on which the spatial restructuring at Treasure Hill would be based. ${ }^{32}$ It was also one of 
the first instances where a common narrative about the space emerged between state and civil society. Moreover, this shift occurred against the backdrop of a modernizing city administration's introduction of "creative city" policies which were aimed at bolstering Taipei's cultural output, just as the country was shifting its manufacturing to mainland China and facing an uncertain economic and political future.

The romanticized view of the marginalized, poor community of villagers began to dominate the discourse on Treasure Hill throughout the negotiations over its fate. Keywords such as "memory," "history," "organic" or "community" came to the fore in many of the pamphlets and statements at the time. Coping with poverty was recast as ingenuity. Building illegal structures became a make-do spirit. Marginalization was reworked into a sense of community. Recasting and mapping the self-sufficient village helped to consolidate a relatable image of Treasure Hill and was an important element that contributed to the success of an art-led conservation which included the original residents. The story of Treasure Hill, as told by conservationists, mirrored the grand narrative of Taiwan, having risen from post-war poverty to Asian Tiger status through hard work, ingenuity and a community spirit (and the protection of the US Seventh Fleet). In a statement dated 18 February 1999, the housing association Tsuei Mama states: "To demolish Treasure Hill would be to demolish 40-odd years of community and neighbour relations, but would also mean destroying a piece of Taipei's history of urban development." 33

By holding up Treasure Hill as a relatable, even generic, history of Taipei, the same keywords formed the basis of the plan to create a cohabitational art village which was presented to the city by OURs. Their plan underlined the importance of the living community as a relatable piece of "our" past and in effect grafted the welfare and social aspect of cohabitation onto the idea of an artist village to publicly memorialize the past and allow its integration into modernity. The 2001 report by National Taiwan University's Graduate Institute of Building and Planning, authored by John K.C. Liu 劉可強, still separated culture and welfare in 2001, but the OURs report in 2004 firmly established the link between the cultural and welfare aspects of the renovation. ${ }^{34}$ The emphasis on memory and space was a crucial step in its preservation, cleverly reappropriating the term "squatter" (previously used by the city to emphasize the villagers' lack of residence rights) as a romanticized piece of Taiwan's history. Simultaneously, however, the search for authenticity avoided questions of individual property rights, which the villagers were insisting on but which remained a red line for the city. Instead, "artivists" (artist-activists) aimed to use the idea of a cohabitational art village as a comprehensive measure to protect the village and its population, transforming the whole illegal village into an outdoor museum. By its own admission, OURs invited artists and organized art festivals with the objective of raising the profile of the area in conjunction with what one of its organizers, Kang Min Jay 康旻杰, called the "highly political and calculated tactics of conservation." ${ }^{35}$ OURs emphasized the inseparability of the cultural value of the place from the presence of the original community and presented itself as the model administrator through a string of mediafriendly events such as a village film society, communal eateries, children's workshops and art interventions aimed at (re)discovering the community at Treasure Hill, most notably the Global Artivist Participation Project (GAPP) in 2003-2004.

The art interventions set in Treasure Hill during this time are described best by Finnish architect-artist Marco Casagrande, who introduced the idea of Treasure Hill as Taipei's "attic": a place where obsolete and forgotten things are stored and to which one may return when searching for answers from the past. ${ }^{36}$ The concept proved immensely popular with the city and remains Taipei's quintessential art intervention to 
this day. It informed curatorial practice and was used on the village's official website - it even provided the name for the Attic youth hostel. The municipal cultural bureau integrated these ways of seeing space into its vision of the village, a perspective which is currently reproduced on guided tours offered to visiting tourists. On one such tour, the guide often stopped to point out where and what Casagrande was collecting and exhibiting (mainly old trinkets, photos and abandoned items), while emphasizing throughout the reaction of the residents: "who from being bewildered at first later realized the importance of old, forgotten objects because of the artist's intervention." 37 The lack of agency for the voiceless residents aside, what is being put into practice here is the idea that art interventions (or creativity in general) can turn around declining communities - a practice replicated elsewhere in Taiwan, from Kaohsiung's Pier-2 Art Centre to the Urban Regeneration Stations in Taipei's Dihua Street 迪化街 (not to mention countless similar projects worldwide). In the case of Treasure Hill, the solution to the double questions of preservation and veterans' housing problems was to construct a hybrid space that could cater to and protect both, while also operate under the constraints imposed by the city administration. The debate was reframed to favour a particular niche authority - identifying, producing and managing authenticity - which OURs and associated groups now commanded, having shown their ability to run the unruly village as a cultural institution during the GAPP. In effect, the problem was recast in a way which necessitated the emergence of a museum-like space, complete with artefacts, expertise, popular appeal and managerial structure.

After groups of experts including OURs and the Tsuei Mama Foundation threw their weight behind a solution they co-created within the framework of the city, the question was not whether the residents would stay but rather under what terms would they stay. Here, divisions first appeared among groups that had previously collaborated on art festivals and cultural events. Chief among the dissenters was a group of artists and activists living and working in Treasure Hill, who organized themselves as the Treasure Hill Commune (Baozangyan gongshe 寶藏巖公社). Their radical goals of letting the village evolve as a spontaneous artist-veteran community set them on a collision course with the increasingly detailed plans which OURs and the city were putting in motion. The community of residents was equally divided, with many supporting OURs plans and many others refusing to leave their houses. While OURs supported a comprehensive legalization of the village as a cultural-welfare site ${ }^{38}$ the Commune advanced its own agenda of preserving diversity by supporting all residents' individual rights of abode regardless of welfare status. ${ }^{39}$

This multi-faceted conflict escalated when OURs published a landmark report commissioned by the city government which made apparent the extent to which the adhoc cohabitational space would be altered. Much of the proposed refurbishment dealt with building safety, utilities, wastewater management and spatial planning. Despite city opposition, OURs also advocated for a retirement-artist community that would outlive the lifespan of current residents and create a long-lasting cohabitational village. But the 550-page report also included detailed social analysis, identifying problematic behaviour such as drinking, noise, lack of hygiene, using open fires indoors and even sexual harassment. ${ }^{40}$ This incited the first altercations between residents and OURs, when an angry resident heckled Kang Min Jay during an international public art symposium held at the Taipei Fine Arts Museum in May 2005. ${ }^{41}$ The language used in the report suggested the future cohabitational village would not tolerate unsuitable tenants, be they artists or original householders. Moreover, by introducing a formal categorization between "good" tenants (who participate in the community, play mahjong and watch films together) and "bad" tenants (who drink, brawl and shout), OURs 
ended up promoting a normative vision of a harmonious cohabitational village, an "ideal community" in Kang Min Jay's words. ${ }^{42}$ While this ideal community would preserve the most vulnerable residents, it excluded groups which were considered to be "tenants" rather than original households. Thus, just as plans were being finalized, questions of residents' property rights increasingly overshadowed the optimistic language of artist-resident cohabitation. What ensued was a conflict over property rather than a curatorial spat.

In late spring of 2006, the municipality finalized the resettlement options available to the residents: they could receive full compensation of NTD720,000 (which was then approximately US\$22,000) and lose their right of abode; they could accept partial compensation of NTD360,000 $(\$ 11,000)$ and figure out their living arrangements on their own during the renovation or rent government temporary housing; or they could forgo compensation and go into temporary housing for free during renovation. ${ }^{43}$ Many residents were dissatisfied with the offered terms. There followed a slew of accusations and counter-accusations, with the Treasure Hill Commune accusing OURs of colluding in property theft, while OURs replied with an equally vitriolic statement accusing the Commune of harassing elderly residents, stirring up dissent and disrupting public order with lewd behaviour. ${ }^{44}$ This heated exchange continued throughout December 2006, with the Commune going as far as accusing OURs of a discriminatory selection process that ignored the real diversity of Treasure Hill's population. ${ }^{45}$

The situation deteriorated further after an interview in the Liberty Times in which Li Bin 李斌, deputy director of the Cultural Affairs Bureau, accused the recalcitrant artists of excessive drinking, drug abuse, and most puzzlingly, of sending scantily clad young women to persuade old veterans not to accept the compensation offer. ${ }^{46}$ Although not unanimous, the Commune received some support from residents who had not yet accepted the official relocation and tenancy plan. At a round table filmed by the Commune, residents repeatedly questioned the very fundamentals of preservation, asking why they were not allowed to refurbish their own houses or participate in the design process. Tellingly, they frequently referred to questions of ownership: "We need to make this clear. These repairs ... They are waiting till they will be repairing their own houses, changing them to the city government and then repairing them, they won't be repairing our houses." Another added: "They're tricking us. What does the refurbishment have [to do] with residency rights? ... If we give up residency, we will never be able to return." ${ }^{47}$ The Treasure Hill Commune collected evidence of resident opposition to justify its own increasingly radicalized stance which culminated in the occupation and protests sparked by the city's decision to clear out the village by 22 December 2006 (shortly after the 2006 municipal elections to avoid any political fallout). Meanwhile, OURs was cautioning that the city might abandon preservation altogether, thus harming the most vulnerable tenants. The end of 2006 brought further conflict, with Xu Shenqing 徐聖情 (deputy leader of the village's own cultural association, which supported the city plan) calling on the new administration to "toughen up" and clear out the squatters, apparently oblivious to the irony of using a term which had in the past been applied to all the village's residents. ${ }^{48}$ Ultimately, the city heeded Xu's call and riot police were called in to clear the remaining squatters (the Commune and other obstinate households ${ }^{49}$ ) out of their homes on the morning of 30 January 2007, at which point Treasure Hill entered a three-year hibernation. Whatever the claims and counterclaims behind the conflict, three points should be reiterated: (a) the expert groups led by OURs successfully persuaded the municipality to adopt their vision of a cohabitational village but failed to get universal approval of the residents; 
(b) the radical artivist group (Treasure Hill Commune) was unable to leverage their relations with unsatisfied residents into political power; and (c) the municipality ultimately needed to resolve the conflict using its coercive apparatus. The deterioration of relations in the village meant that the municipality, rather than any civil society group, would be calling the shots in the future.

With the radical artist community and other dissenters forcibly removed, the villagers would now be tenants living in a protected landmark, paying rent to the city in return for their right to return to their houses following renovation, which had been entrusted to the architecture firm owned by the head of OURs, Liu Keqiang 劉可強. Following the reopening in 2010, civil society organizations such as OURs were increasingly sidelined in the running of the site as Taipei's creative city policies took precedent over the provision of welfare and community organizing. Alongside the remaining veteran households, the future artists of Treasure Hill would now be selected through an official application process designed to facilitate cohabitation under the benevolent control of the municipality and its arms-length bodies such as the Taipei Culture Foundation. The long process of the village's entry into the city's administrative landscape was finally complete.

\section{Treasure Hill 2: From Cohabitation to Spatial Taxidermy}

If Treasure Hill Artist Village is a consequence of a collaboration between the city and spatial experts, what does the space of Treasure Hill say about this collaboration? In terms of the experts' authority, how did its integration into the city bureaucracy affect the spatial manifestation of the artist village? What practices were preserved and which were cast aside? Based on a longitudinal observation over a period of eight months, the ethnography of the space dealt with these questions by focusing on who the space is for, how it is used, how it is made attractive and what happens there, all of which speak to its authenticity and museumification.

Following renovation, Treasure Hill ran three art and design-based programmes in addition to the youth hostel and its social housing role. Owing to the fast turnover of the foreign and domestic art residencies, the third and most stable part of the art village, the MicroLoft programme, was examined in more detail. From its inception in 2010, MicroLoft spaces have been encouraged to open up to the visiting public. Since the first eight spaces were allocated, the number of cafes alone has increased from one to five out of the total of 14 lots in 2013. Other MicroLoft spaces are required to open their doors to visitors on official open days, selling products such as artisanal paper or jewellery, and offering workshops or tours of the studios. In effect, the MicroLoft programme provides the consumable content for visitors. While sales contribute to the young artists' income, the presence of a constant stream of visitors can also be distracting. Several of the MicroLoft tenants went so far as to complain about the number of visitors, even during closed days: "I had to install blinds on my windows, because people were taking photographs of me ... sometimes they would also barge in, without knocking even." ${ }^{50}$ As the MicroLoft is a desirable and inexpensive place to work, many of the artists I interviewed also admitted they overemphasized the "social" aspect of their work during the application process to improve their chances but then found that opportunities for interactions with the elderly residents were few and far between; workshops were at best attended by children, whereas some of the older men were outright hostile to their presence.

Indeed, to address the issue of insufficient interaction, the organization of social activities was handed over to Xuri Cultural Enterprises Ltd. (Xuri wenhua shiye youxian gongsi 旭日文化事業有限公司), which was also headquartered at Treasure 
Hill and managed relations between residents and artists. Some community traditions, such as sharing meals, were re-introduced following the hill's transformation into an artist village. However, the reduced number of residents (19 in 2018, down from 21 households in 2014, compared to over 70 before the evictions and renovation in 2007) and the relatively fast turnover of young artists preclude the establishment of any lasting and spontaneous links typical of a lived, organic community. While the intent may have been to ease communication between the constituent groups in the village, the rerouting of informal links onto a formal framework was not always successful. The resulting ritualization of spontaneous social gatherings within a systematic schedule underlines the difficulty of creating authenticity through administrative fiat. Although the tools developed to manage the area pay homage to former community practices researched and praised by OURs, they were now managed by the city through an outsourcing model. When Xuri's contract ran out, social events were entrusted to Vis Video Production, a purely for-profit company, introducing further commercialization into the running of events in the village. This is in direct contradiction to the plans drawn up by OURs in 2004, which envisaged only non-profit participation and emphasized community solutions over outside control. Moreover, when new units became available as original residents left or died, the city decided to use the space to open a media school in 2015. These changes show the municipality sees Treasure Hill predominately as a cultural and tourist venue, casting aside plans for replenishing the population of elderly residents which were drawn up by OURs. ${ }^{51}$ Instead, Treasure Hill has been integrated fully into the municipality's "creative city" strategy of urban development.

The resulting arrangement of cohabitation is a "spatial taxidermy" of the successful and well-attended artivism of the 2003-2004 period. Shorn of its radical ideas of spontaneous communitarianism, it had become a carefully presented exhibit, a ritual which visitors observe from afar and which lends the place an easily understandable authenticity. Herein lies a core component of the museumification of Treasure Hill: rather than changing the population of the area (as happens with slum clearance or gentrification), the municipality managed to alter the space of the village from a spontaneous place to a staged scene. This preserved the human as well as nonhuman actors, both beings and things, but also valorized them as a publicly accessible exhibit.

Treasure Hill Artist Village remains a popular tourist destination. Walking around the village, one immediately notices signs stating "Treasure Hill Homeland, please do not enter without invitation" (Baozang jiayuan: jumin zhusuo, qing wu jinru 寶藏家園: 居民住所, 請勿進入). ${ }^{52}$ These signs are meant to protect the remaining households from the unwelcome intrusions of uninvited visitors but also add to the impression of being in a living museum - "Do not lean on the glass"; "Do not photograph"; "Do not touch the exhibits." The signs themselves have taken on the life of an exhibit. Indeed, I noticed visitors taking photographs in front of them on several occasions during my visits. When I asked why they were doing this, a young couple replied that they felt it gave the place authenticity - literally, that "the signs ... make you feel it really is a village." 53 The residents of Treasure Hill, together with the resident artists, have found themselves in the role of exhibits/exhibitors, their vegetable patch or their post boxes being as much an object of the tourists' gaze as the art installation next door.

\section{Museumification, Not Gentrification}

Treasure Hill operated as a policy laboratory for the involvement of non-governmental 
expert communities in producing and governing creative spaces, a practice which continues in other programmes around Taipei. The formation of "best practice" at Treasure Hill is already having an impact on other instances of regeneration using the creative city discourse. ${ }^{54}$ In effect, the city showed substantial adaptive capacity by loosely integrating the expert input into the city's bureaucracy under the umbrella of the Taipei Culture Foundation, a quasi non-governmental organization first set up in 1985 that has since 2007 taken on the responsibility of running a variety of venues and events in Taipei. In Treasure Hill, the foundation acted as a vehicle that accommodated spatial expertise into existing bureaucratic structures, resulting in the museumification of the village. This aligned managerial practice (enforcing reports, periodic reviews) and language and concepts (community, creativity), and facilitated horizontal integration with the city's growing number of culture-led regeneration projects. Treasure Hill was thus placed in the same administrative structure as the Taipei Museum of Contemporary Art, the Red House in Ximen 西門, the Songshan Cultural and Creative Park or the Taipei Performing Arts Centre, all of which represent highprofile spaces constituting what a chief urban planner called "new Taipei urbanism." 55

Although the THAV operates as part of this semi-public institution, it externally resembles a neighbourhood rather than an institution. Critical voices, especially in Taiwan's academic and art community, have suggested that Treasure Hill is a case of gentrification. ${ }^{56}$ Gentrification can indeed be understood as a valuation of authenticity (of space, lifestyle, architecture, etc.) that creates a "rent gap" - the key mechanism fuelling gentrification in Neil Smith's classic account. ${ }^{57}$ Yet owing to the close involvement of spatial experts, municipal authorities and professional associations, I argue that museumification better encapsulates the evolution and set-up of the village and is a direct consequence of accommodating expert authority rather than market-led change. While reminiscent of many aesthetic aspects of gentrification (nostalgia, commercialization of memory, displacement of poor residents, etc.), museumification is at its core an institutionalization of space, which in this case was founded upon a discovery of a relatable authenticity of the village. Unlike gentrification, moreover, museumification attempts to preserve a curatorially defined state of affairs rather than subject it to an endless logic of market-led "upgrading." Approaching the space as a museum, it becomes clear the remaining residents and artists are in fact exhibits in a living diorama.

The shared ideas of authenticity that formed a two-way conduit between experts and the city, and through which municipal practices of control entered the artist village following its reopening in 2010, encompass artistic, social, commercial and even bodily issues (such as hygiene complaints, etc.). The level of control over daily affairs within the institutionalized village suggests that although the size of the museumvillage is small, the breadth of governing is not. It includes managing quotidian affairs such as eating, socializing and welfare provision, but also maintains a village identity that fits into city policies such as Taipei's successful bid for "World Design Capital" in 2016. It is hard to overlook the seemingly conflicted use of both high-modernist and neoliberal approaches, both the normative and intrusive micromanagement by the city, and the outsourcing of this micromanagement to private bodies. Museumification, having relied on exploring, documenting and ultimately enforcing authenticity, resulted in this curious mix because it serves two distinct goals: preservation and exhibition.

Treasure Hill Artist Village is subject to pressures most museums face - to reproduce an acceptable aesthetic and to provide a normative, even didactic, role. Simultaneously, it also replicates the administrative patterns of modernist population 
control. This set-up represents the final stage in the recasting of a marginal migrant village as a matter for cultural intervention. What was an urban aesthetics issue had become a hybrid social and cultural site managed first by the expertise of OURs and later passed on to the city. In its latter role as part of a citywide effort to rebrand Taipei as a city of design and creativity, Treasure Hill contributed to the institutionalization of spatial expertise not only as an inspiration but also as a path-blazing template.

\section{Conclusion}

The steep hills and alleys of Treasure Hill house a curious mix of authenticities as well as authorities, not to mention the art. The migrant village survives as a planned cultural space that the now elderly migrants still occupy alongside artsy cafes and galleries selling craft souvenirs. Although the village shows signs of "gentrification," this article has argued that the museological approach to the production of this space is based on an altogether different process: a methodical transformation of the village into a municipal museum that caters to Taipei's flâneurs and slots into municipal cultural policies. This museumification translated a vernacular marginal space into a consumable and approachable destination for contemporary visitors wishing to experience life in a community of veterans and urban artists while enjoying a bubble tea and appreciating art. Stemming from a shift to a post-industrial urbanity, the authenticity of the museum's exhibit was contingent on a process of negotiation and conflict between residents, radical artists, spatial experts and an engaged municipality. Those opposed to the refurbishment saw OURs merely as an agent of the city, yet the survival of Treasure Hill without the expert interventions is highly doubtful. This highlights the difficulty of balancing grassroots community action (which is what OURs aspired to) with the exigencies of governance (which is what OURs had to do). As the small community of elderly mainland Chinese veterans diminishes, their living spaces are destined to become new wings of this outdoor museum. While the homes they built will be preserved, the process of preservation needs to be considered in in its rightful context as a museumification, a form of governance marrying top-down administrative expertise with input from the creative city toolbox, rather than filed away under an increasingly stretched rubric of gentrification.

\section{Acknowledgements}

I thank my mentor, Professor Julia Strauss, for her unyielding support in the face of my doubts, and my husband, Silas, for his good-humoured stoicism. The underlying research was supported by an ERCCT fellowship.

\section{Conflicts of interest}

None.

\section{Biographical note}

Igor ROGELJA is based at the Lau China Institute, King's College London. Infrastructure and spatial politics remain the focus of his work.

摘要: 本文讨论了, 在更广泛地议论关于城市边缘空间的士绅化与再开发的语 境下，台北市一个城中村博物馆化成为 “宝藏岩国际艺术村”的演化过程。作为 第二次国共内战后，撤离至台湾的士兵们栖居之所的眷村，“宝藏岩”结合成为 了一种混合型空间, 既对老兵提供福利, 又作为艺术家庄园部分性地构建了台 北文化基金会。这一博物馆化的动态过程被誉为一种融合社会, 文化及经济等 
各方面的城市化复兴的和解, 其结果混合着高度现代主义者的父爱主义及新自 由主义的地方营造。因而得以在空间中, 将作为一种博物馆式机构的现存城市 官僚体制与年长的居民及艺术家，整合成为鲜活透视图中的展品。虽然在不同 时间里被广泛地理解为“士绅化,”但本文试图论证 “宝藏岩”的博物馆化是一个由 政府及空间专家所组成的同盟引领的建构过程。并且这一过程, 对研究政府主 导的邻域改善问题有着显著的影响。

关键词：博物馆化; 创意城市; 台湾; 士绅化; 真实性

\section{References}

Abers, Rebecca N., Keck, Margaret E., 2013. Practical authority: Agency and institutional change in Brazilian water politics. New York: Oxford University Press.

Braester, Yomi. 2007. "The impossible task of Taipei films.” In William Darrell Davis and Ru-shou Robert Chen (eds.), Cinema Taiwan: Politics, Popularity and State of the Arts. London: Routledge, 50-59.

Brownlow, Ron, Kelly Lin, 2007. "Last stand for veterans' villages" Taipei Times http://www.taipeitimes.com/News/feat/archives/2007/03/04/2003351007/1 Accessed 22 April 2015.

Casagrande, Marco. 2006. "Dushi de zhenjiu" (Urban acupuncture). Jianzhushi zazhi 2006(12), 88-89.

Chun, Allen. 1994. "From nationalism to nationalizing: cultural imagination and state formation in postwar Taiwan." The Australian Journal of Chinese Affairs No. 31 (January), 49-69.

Cliver, Gwyneth. 2014. "Ostalgie revisited: the musealization of Halle-Neustadt." German Studies Review 37(3), 615-636.

Corcuff, Stéphane. 2002. Memories of the Future: National Identity Issues and the Search for a New Taiwan. Armonk, NY: M.E. Sharpe.

Dellios, Paulette. 2002. "The museumification of the village: cultural subversion in the 21st century." Cultural Mandala 5(1) Art 4, 1-16,

https://cm.scholasticahq.com/article/5848-the-museumification-of-the-villagecultural-subversion-in-the-21st-century. Accessed 14 January 2020.

Florida, Richard L. 2002. The Rise of the Creative Class: And How It's Transforming Work, Leisure, Community and Everyday Life. New York: Basic Books.

Handler, Richard. 1986. "Authenticity." Anthropology Today 2(1), 2-4.

Howard, Peter. 2002. "The eco-museum: innovation that risks the future." International Journal of Heritage Studies 8(1), 63-72.

Huang, Sun-quan. 2012. Lüse tuituji: 90 niandai Taibei de weijian, gongyuan yu zhiduhua dijing (Green Bulldozer: The Squatters, Parks, Nature Estate and Institutionalized Landscape of 90'’ Taipei). New Taipei City: Indymedia.

Kang, Min Jay. 2005. "Identity politics and community artivism: a strategic arts project of cultural landscape preservations at Treasure Hill, Taipei." In Jeffrey Hou, Mark Francis and Nathan Brighbill (eds.), (Re)constructing Communities: Design Participation in the Face of Change. Davis, CA: Center for Design Research, University of California, Davis, 153-169.

Landry, Charles. 2008. The Creative City: A Toolkit for Urban Innovators. London: Earthscan. 
Lin, Hongzhang. 2006. "Xiazi yu xiang: shishenhua zhong de Baozangyan" (Can't see the wood for the trees: gentrifying Treasure Hill). Jin yishu October, 148-153.

Linnekin, Jocelyn. 1991. "Cultural invention and the dilemma of authenticity." American Anthropologist 93(2), 446-49.

Liu, Keqiang. 2001. "Zhongzheng 297 hao (Yongfu) gongyuan yi juluo gongyuan xingtai baoliu kexingxing yanjiu" (Report on the feasibility of preserving the number 297 Zhongzheng Park (Yongfu) as a settlement-park type). Taipei City Government.

Liu, Sung-ta. 2013. "Settler urban legacies: A case study of Taipei City." Cities 31, 239-247.

Marcuse, Peter. 2003. "Review of The Rise of the Creative Class by Richard Florida." Urban Land 62, 40-41.

Miller, Peter, and Nikolas Rose. 2008. Governing the Present: Administering Economic, Social and Personal Life. Cambridge: Polity.

Müller, Michael. 1999. "Musealisation, aestheticisation and reconstructing the past." The Journal of Architecture 4(4), 361-67.

$\mathrm{Ng}$, Mee Kam. 2015. "Knowledge and power in regenerating lived space in Treasure Hill, Taipei 1960s-2010: from squatter settlement to a co-living artist village." Planning Perspectives 30(2), 253-270.

O'Connor, Justin. 2007. "The cultural and creative industries: a review of the literature. A report for creative partnerships." Creative Partnership Literature Reviews. London: Arts Council England.

OURs (Organization of Urban Re-s). 2004. "Gongsheng yizhan: Baozangyan lishi juluo shezhi yishucun jihua weituo guihua qimo baogao" (Cohabitational Artsville: Treasure Hill historical settlement art village final planning report). Taipei: Taipei City Cultural Bureau.

OURs. 2006. "OURS yanzheng huiying "Baoshan baozha: "juluo huohua" zhi huangyan chaichuan de yinbaodian' yiwen" (OURs sternly responds to the text "Baoshan explosion - the tipping point on lies over 'settlement activation"'), https://groups.google.com/forum/\#!msg/yotu/NZbKrHb303k/SmskS6gp95sJ. Accessed 6 August 2019.

Peck, Jamie. 2005. "Struggling with the creative class." International Journal of Urban and Regional Research 29(4), 740-770.

Phillips, Steven E. 2003. Between Assimilation and Independence: The Taiwanese Encounter Nationalist China, 1945-1950. Stanford, CA: Stanford University Press.

Rogelja, Igor. 2014. "The Production of Creative Space in Taiwan and China." PhD diss., School of Oriental and African Studies, University of London.

Selwyn, Tom. 1996. The Tourist Image: Myths and Myth Making in Tourism. Chichester: John Wiley \& Sons.

Smith, Neil. 1979. "Toward a theory of gentrification: a back to the city movement by capital, not people." Journal of the American Planning Association 45(4), 538548.

Theodossopoulos, Dimitrios. 2013. "Laying claim to authenticity: five anthropological dilemmas." Anthropological Quarterly 86(2), 337-360.

Treasure Hill Commune. 2006. "Wenhua tuituji shixian 297" (Culture Bulldozer reaches 297), http://www.coolloud.org.tw/node/264 . Accessed 6 August 2019.

Tsuei Mama Foundation. 1999. "Taibei de Diaojingling: Baozangyan de gushi" (Taipei's Tiu Keng Leng: the story of Treasure Hill). Unpublished statement, 18 February, 
http://bbs.nsysu.edu.tw/txtVersion/treasure/tmm/M.969213545.A/M.1050291767 .A/M.1050292042.V.html. Accessed 10 August 2019.

Urry, John. 2002. The Tourist Gaze (Second edition). London: Sage.

Urry, John, and Jonas Larsen. 2011. The Tourist Gaze 3.0. London: Sage.

Wedeen, Lisa. 2010. "Reflections on ethnographic work in political science." Annual Review of Political Science 13, 255-272.

$\mathrm{Xu}$, Shenqing. 2006. "Jujie zai zuo ruanshizi, Xinshifu qing ying qilai” (New city administration should refuse to be bullied and toughen up). Treasure Hill Cultural Village Association, http://www.coolloud.org.tw/node/263. Accessed 20 April 2016.

Yu, Dan, and Ji Xiao (dirs.). 2006. "Treasure Hill residents and resident artist Li Guomin, Treasure Hill Commune meeting" (unpublished video recording), 18 February, https://youtu.be/Ke3y15ZUoD0. Accessed 4 August 2019.

Zhang, Li-ben. 2011. "Qu niu de jingzi: Baozangyan de minzhong, kangzhengzhe, yishu yu tizhi” (Twisted mirror: Treasure Hill's people, protesters, planners, artists and institutions." Wenhua yanjiu yиеbao 122, 57-63.

Zheng, Xue Yong. 2006. "Baozangyan zhengjian duan shuidian minzhong fenglu kangzheng" (Utilities cut off during Treasure Hill renovation, protesters close road). Liberty Times, 23 December.

Žižek, Slavoj. 2002. Welcome to the Desert of the Real! Five Essays on September 11 and Related Dates. London: Verso. 
${ }^{1}$ Accessible at http://www.taipeiculture.org.tw/English/14.html. Accessed 30 April 2015.

${ }^{2}$ The creative city discourse largely stems from two shifts in urban policy: a macro-economic move from an industrial economy to a service-oriented "creative" economy fitting a neoliberal shift in urban policy (inter-city competition, place-making, replacing plans with strategies, public-private partnerships), and a micro-level expounding on the virtues of creativity in individuals (see Florida's (2002) notion of the "creative class"), which urban governments should attempt to attract. For critiques of the creative class idea, see Marcuse's $(2003,41)$ suggestion that the notion merely describes "lifestyle preferences of yuppies," while Peck $(2005,766)$ suggests creative city discourses "reconstitute urban-elitist 'leadership' models of city governance ... in the form of an increasingly clichéd repertoire of favored policy interventions."

${ }^{3}$ Landry 2008

${ }^{4}$ The term spatial experts refers to a loose professional grouping of architects, urban scholars, housing activists and artists working in the built environment. The choice of the term "spatial" over "urban" or other cognate terms emphasizes their comprehensive efforts at producing spaces, rather than remaining at the level of the plan.

${ }^{5}$ The official military barracks were demolished in 1994 by the Ministry of National Defence.

${ }^{6}$ Chun 1994, 56

${ }^{7}$ Phillips 2003, 9 .

${ }^{8}$ Liu 2013.

${ }^{9}$ Corcuff 2002, 166.

${ }^{10}$ Huang 2012.

${ }^{11}$ Brownlow and Lin, 4 March 2007.

${ }^{12}$ Braester 2007, 56.

${ }^{13}$ Handler 1986; Linnekin 1991; Theodossopoulos 2013.

${ }^{14}$ Selwyn 1996.

${ }^{15}$ Urry 2002.

${ }^{16}$ Urry and Larsen 2011, 1-3.

${ }^{17}$ Žižek 2002, 6.

${ }^{18}$ Wedeen 2010, 267.

${ }^{19}$ Abers and Keck 2013, 3.

${ }^{20}$ See Dellios 2002 on cultural villages in East Asia.

${ }^{21}$ See Müller 1999 on musealization and aesthetization in urban design in Germany.

${ }^{22}$ See Cliver 2014 on Halle-Neustadt.

${ }^{23}$ Howard 2002.

${ }^{24}$ O'Connor 2007.

${ }^{25}$ Miller and Rose 2008, 35.

${ }^{26}$ Liu 2001.

${ }^{27}$ Rogelja 2014.

${ }^{28}$ Interview with Treasure Hill site manager, Taipei, 4 April 2013.

${ }^{29} \mathrm{Ng} 2015,258$.

${ }^{30}$ While OURs is an acronym of "Organization of Urban Re-s," its name in Mandarin is less cryptic, translating as the Association of Urban Reform Experts (Zhuanyezhe dushi gaige zuzhi). Founded in 1992, it includes architects, urban planners and other spatial professionals concerned about Taiwan's urban problems. Like Tsuei Mama, OURs sprang from the protests on 26 August 1989 against homelessness and rising real-estate prices.

${ }^{31}$ Arte povera was an avant-garde art movement in Italy in the 1960s, which aimed to challenge existing hierarchies by using "impoverished" materials and bridging the gap between the natural and the artificial. ${ }^{32}$ Lin 2006; personal communication with Lin Hongzhang, 9 October 2013.

${ }^{33}$ Tsuei Mama Foundation 1999.

${ }^{34}$ Liu 2001; OURs 2004

${ }^{35}$ Kang 2005, 155

${ }^{36}$ Casagrande 2006, 9.

${ }^{37}$ Treasure Hill tour guide, 21 March 2013.

${ }^{38}$ OURs 2004, Appendix/57.

${ }^{39}$ Treasure Hill Commune 2006.

${ }^{40}$ OURs 2004, 2/37.

${ }^{41}$ Footage of the incident is available at: https://youtu.be/rlPXfmzjFKw. Accessed 4 August 2019.

${ }^{42}$ OURs 2004, Appendix/58.

${ }^{43}$ Taipei City, November 2006. 
${ }^{44}$ OURs 2006.

${ }^{45}$ Treasure Hill Commune 2006.

${ }^{46}$ Zheng 2006.

${ }^{47}$ Video of Treasure Hill residents meeting, Yu and Xiao 2006.

${ }^{48} \mathrm{Xu} 2006$.

${ }^{49}$ Footage of the police eviction is available at: https://youtu.be/F2NkpCOti4s. Accessed 4 August 2019.

${ }^{50}$ Interview with Li Mengshu, resident MicroLoft artist, Taipei, 17 March 2013.

${ }^{51}$ OURs 2004, App/56-57.

${ }^{52}$ Tellingly, Ng also points out the signs. Ng 2015.

${ }^{53}$ Interview with Treasure Hill visitors. Taipei, 21 March 2013.

${ }^{54}$ Rogelja 2014.

${ }^{55}$ Interview with Hsu Yanhsing, Taipei City Urban Regeneration Office deputy head, Taipei, 30 April 2013.

${ }^{56}$ Most notably Lin 2006 and Zhang 2011. Ng 2015 similarly favours this term.

${ }^{57}$ Smith 1979. 